\title{
Administrative Barriers in the Field of Employment in the EU: Empirical Evidence from Croatia and Slovenia
}

Submitted 25/02/20, 1st revision 21/03/20, 2nd revision 15/04/20, accepted 20/05/20

\author{
Alka Obadić ${ }^{1}$, Dejan Ravšelj ${ }^{2}$, Aleksander Aristovnik ${ }^{3}$ \\ Abstract:
}

Purpose: Administrative barriers to employment pose a problem in Small and Medium-sized Enterprises (SMEs) which have an essential role in the European economy, compared to large ones. The existing rigidity and inflexibility of the labor market have further slowed down their position in creating new jobs. Therefore, the main goal of this paper is to evaluate the current state of administrative barriers to employment for SMEs in Croatia and Slovenia. Design/methodology/approach: Applying descriptive statistics and one-way analysis of variance (ANOVA) on a survey data for 699 Croatian and 747 Slovenian SMEs.

Findings: The empirical results on a sample of about 700 SMEs for both countries expose some differences between them. In respect of administrative barriers to employment for SMEs, the most noticeable problem in Croatia is associated to frequent changes in the regulation, while in Slovenia the most highlighted problem is associated to additional time and unnecessary number of documents. Moreover, the empirical results reveal significant differences concerning the perception of the extent of administrative barriers to employment between different groups of SMEs, whereby not all of the characteristics have the same implications on this perception.

Practical Implications: The overall findings are important especially for economic policy makers, who need to consider the specific characteristics and needs of SMEs when preparing legislation.

Originality/Value: The combination of primary research and comparative perspective represents the main originality and value of the paper.

Keywords: SMEs, administrative burdens, employment, Croatia, Slovenia, EU.

JEL Codes: J80, L26.

Paper type: Research study.

Acknowledgments: The authors acknowledge the financial support from the Slovenian Research Agency (bilateral project BI-HR/16-17-009 and research core funding No. P50093).

\footnotetext{
${ }^{1}$ Ph.D., Full Professor, University of Zagreb, Faculty of Economics and Business, Zagreb, E-mail:aobadic@efzg.hr

${ }^{2}$ Ph.D., Senior Assistant, University of Ljubljana, Faculty of Public Administration, Ljubljana, E-mail: dejan.ravselj@fu.uni-lj.si

${ }^{3}$ Ph.D., Full Professor, University of Ljubljana, Faculty of Public Administration, Ljubljana, E-mail: aleksander.aristovnik@fu.uni-lj.si
} 


\section{Introduction}

Small and Medium-sized Enterprises (SMEs) have a crucial role in the European economy, as they represent the engine of job creation and economic growth. Currently, SMEs in the European Union (EU) represent $99.8 \%$ of all enterprises, providing $66.6 \%$ of employment and 56.4\% of value added (European Commission, 2019a). However, in comparison with the large enterprises, SMEs often have worse performance, which is reflected in lower profitability, higher staff turnover, lower rate of survival etc., (European Parliament, 2016). The main cause of the aforementioned problems arises presumably from a variety of barriers that SMEs encounter in the EU (Ravšelj et al., 2019). Generally, SMEs do their business within their national market, since relatively few SMEs are engaged in cross-border business within the EU (Lewandowska and Stopa, 2019). However, they are affected by EU legislation in different areas, such as taxation, competition and company law. Accordingly, the EU policy for SMEs strives to ensure that policies and actions are implemented in a way, which is friendly for the business environment in which SMEs operate. Consequently, this will make the EU a more attractive place to set up an enterprise and do business (European Parliament, 2017).

According to the previously emphasized importance of SMEs for the economic growth of each economy, the main aim of this paper is to assess the current state of administrative barriers to employment for SMEs in Croatia and Slovenia. Namely, SMEs often emphasize that administrative and regulatory barriers are perceived as a significant burden on their growth and competitiveness (Obadić, 2018; Ravšelj and Aristovnik, 2018). Therefore, the reduction of administrative barriers for entrepreneurship has become an increasingly important area for economic policy makers. Namely, the costs for smaller enterprises are usually much higher than for larger enterprises and therefore several EU member countries try to consider their specific characteristics and needs into account when preparing legislation. In this context, the European Parliament has been recognised a supporter of a growthfriendly environment for SMEs on the EU supranational level (Obadić, 2018).

The economic literature emphasize that SMEs face numerous barriers primarily due to their size (Szczepaǹski, 2016). Moreover, some of the empirical studies also highlight the importance of other characteristics such as legal form, sector, region, etc., (Aliu et al., 2019; Obadić, 2018; Ravšelj and Aristovnik, 2020). Therefore, reducing administrative barriers represents a central issue that needs to be addressed in order to improve the business environment and competitiveness and increase job creation as it is emphasized in the recent scientific literature (Belas et al., 2019; Hamplova and Provazníková, 2015; Kamil et al., 2017; Ntaliani and Costopoulou, 2017; van der Horst et al., 2017; Virglerova et al., 2016).

Given the importance of SMEs for job creation and economic growth in the EU as well as in individual national economies, the paper examines the relationship between SMEs characteristics and their perception of administrative barriers in the 
area of labour market regulation by considering cross-country perspective between Croatia and Slovenia. Based on this, the following two research questions are proposed and addressed in this paper: RQ 1: What is the perception of SMEs on administrative barriers to employment? and RQ 2: Do the characteristics of SMEs affect the perception of the extent of administrative barriers to employment?

Based on this, the main research hypothesis concerns that there exist significant differences in the perception of the extent of administrative barriers between different groups of SMEs. The remaining sections of the paper are structured as follows. The second section presents the theoretical background and literature review. In the third section, a description of data and research method is provided. In the fourth section the empirical results are presented. The paper ends with conclusion, where main results are summarized.

\section{Theoretical Background and Literature Review}

Theoretical analysis in this part of the paper delivers results of the literature review that begins with fundamental definitions of the SMEs in context of the importance of their economic influence in national economies. The analysis provided in this paper shows condition and structure of SMEs in the EU-28 area and theoretical overview of the administrative barriers which is used for further understanding of barriers at the labour market.

\subsection{Significance of Small and Medium-Sized Enterprises in the EU}

Huge importance of SME sector has made the EU follow active policy supporting entrepreneurship as well as small and medium enterprises. Due to this fact, one of the priorities identified by European Commission is to support micro, small and medium enterprises in order to stimulate economic growth, create new jobs as well as promote economic and social cohesion (Samitowska, 2011; Pisar and Bilkova, 2019). Small and Medium-sized Enterprises are mostly defined by the number of persons employed, total income or exports, although the definitions differ between countries and institutions. As Hyman points out, the most common criterion used is the number of employees (Hyman, 1989).

The limits for the number of employees for individual enterprise size differ between national statistical systems. Thus, some countries set a limit of 200 employees for SMEs, while SMEs in the United States of America (USA) include enterprises with less than 500 employees. Small enterprises are generally those with fewer than 50 employees, while micro enterprises have up to ten or, in some cases, five employees (OECD, 2000). The most common upper limit for the number of employed persons in the EU countries is 250. The definition of enterprise size used in this paper is based on the definitions used by the European Commission's Statistical Office (Eurostat) in its Structural Business Statistics (SBS). This definition is primarily based on the number of employees, but also defines SMEs as a business with less 
than 250 employees, annual turnover of less than EUR 50 million and total balance less than EUR 43 million (European Commission, 2003). The following Table 1 shows the most commonly used division of SMEs within is possible to distinguish three categories of enterprise size: micro, small and medium-sized enterprises.

Table 1. Definition of small and medium sized enterprises in the EU

\begin{tabular}{|l|l|l|l|}
\hline $\begin{array}{l}\text { Enterprise } \\
\text { category }\end{array}$ & Employees & Turnover & Total balance \\
\hline Micro & $<10$ & $<2$ million EUR & $<2$ million EUR \\
\hline Small & $<50$ & $<10$ million EUR & $<10$ million EUR \\
\hline Medium & $<250$ & $<50$ million EUR & $<43$ million EUR \\
\hline
\end{tabular}

Source: European Commission (2003).

SMEs form the backbone of the European economy are making a significant contribution to the non-financial business economy (Table 2). In 2018, slightly more than 25 million of SMEs (99.8\% of total registered enterprises) in the EU-28 area employed 97.7 million people (66.6\% of total employment) and created 4,357 billion value added (56.4\% of total value added generated). According to the size of SMEs, micro enterprises were the most common size of enterprise in 2018, accounting for $93.0 \%$ of total registered enterprises. They also contributed the largest shares of both employment and value added at $29.7 \%$ and $20.8 \%$ respectively. In recent years, SMEs have followed a solid growth path in the EU economy. In 2014-2018, SMEs employment increased by $8.2 \%$, indicating their flexibility and ability of creating new jobs (Obadić and Aristovnik, 2016). Consequently, SMEs value added increased by $16.2 \%$ in this period. The main drivers of growth in SMEs value added were micro enterprises, generating value-added growth of $18.3 \%$ in this period. Nevertheless, the growth in value added of large firms was even higher, at $19.5 \%$. Most recently, in 2017-2018, SMEs in all EU Member States generated growth in both employment and value added, of $1.8 \%$ and $4.1 \%$ respectively. Micro enterprises grew fastest in 2017-2018, with a rise of $2.6 \%$ in employment and $5.4 \%$ in value added. This meant they outperformed the growth in all other business size classes, including that of large enterprises (European Commission, 2019a).

Table 2. Structure of enterprises in EU-28, Croatia and Slovenia according to different indicators (in \%), 2018

\begin{tabular}{|l|l|l|l|l|l|l|l|l|l|}
\hline \multirow{2}{*}{$\begin{array}{l}\text { Enterprise } \\
\text { category }\end{array}$} & \multicolumn{2}{|l|}{$\begin{array}{l}\text { Number } \\
\text { enterprises }\end{array}$} & \multicolumn{3}{|l|}{$\begin{array}{l}\text { Number of persons } \\
\text { employed }\end{array}$} & \multicolumn{2}{l|}{ Value added } \\
\cline { 2 - 11 } & EU-28 & HRV & SVN & EU-28 & HRV & SVN & EU-28 & HRV & SVN \\
\hline Micro & 93.0 & 90.9 & 94.7 & 29.7 & 29.6 & 34.8 & 20.8 & 19.7 & 23.7 \\
\hline Small & 5.9 & 7.5 & 4.3 & 20.1 & 20.9 & 18.3 & 17.6 & 20.0 & 19.5 \\
\hline Medium & 0.9 & 1.2 & 0.8 & 16.8 & 18.4 & 18.9 & 18.0 & 19.7 & 21.3 \\
\hline SME total & $\mathbf{9 9 . 8}$ & $\mathbf{9 9 . 7}$ & $\mathbf{9 9 . 8}$ & $\mathbf{6 6 . 6}$ & $\mathbf{6 8 . 9}$ & $\mathbf{7 2 . 0}$ & $\mathbf{5 6 . 4}$ & $\mathbf{5 9 . 4}$ & $\mathbf{6 4 . 5}$ \\
\hline Large & 0.2 & 0.3 & 0.2 & 33.4 & 31.1 & 28.0 & 43.6 & 40.6 & 35.5 \\
\hline Total & $\mathbf{1 0 0 . 0}$ & $\mathbf{1 0 0 . 0}$ & $\mathbf{1 0 0 . 0}$ & $\mathbf{1 0 0 . 0}$ & $\mathbf{1 0 0 . 0}$ & $\mathbf{1 0 0 . 0}$ & $\mathbf{1 0 0 . 0}$ & $\mathbf{1 0 0 . 0}$ & $\mathbf{1 0 0 . 0}$ \\
\hline
\end{tabular}

Note: Due to rounding, some categories may not add up to $100 \%$.

Source: European Commission (2019a). 
In Croatia, 149,541 SMEs (99.7\% of total registered enterprises) employed 716,562 people (68.9\% of total employment) and created 14.9 billion value added $(59.4 \%$ of total value added), while in Slovenia 145,996 SMEs $(99.8 \%$ of total registered enterprises) employed 466,092 people (72.0\% of total employment) and created 15.8 billion value added (64.5\% of total value added). This reveals that although the share of SMEs in Croatia and Slovenia is similar, the Croatian SMEs provide lower share of employment and lower share of value added than Slovenian SMEs. Moreover, an in-depth comparison between the structure of SMEs in Croatia and Slovenia reveals the following. Regarding the number of enterprises, Croatia has a lower share of micro enterprises and larger shares of SMEs than Slovenia. Considering the number of persons employed, the employment share in Croatia is lower in micro enterprises, larger in small enterprises and similar in medium enterprises in comparison with Slovenia. Finally, the share of value added in Croatia is lower in micro enterprises, similar in small enterprises and lower in medium enterprises compared to Slovenia. Nevertheless, the most common size of SMEs in both countries are micro enterprises, representing more than $90 \%$ of total registered enterprises and providing about $1 / 3$ of total employment and about $1 / 5$ of total value added.

Compared with large companies, SMEs often produce slightly weaker results, such as lower profitability, higher employee fluctuation, lower survival rates, less innovation success, lower investment capacity for development and improvement of employees, etc., (Szczepaǹski, 2016). This can partly be attributed to the existence of significant obstacles to the entry of new employees and growth, which is characteristic for most economies. Smaller companies are faced with disproportionately greater regulatory barriers compared to larger companies (Aristovnik and Obadić, 2015), and inefficient public administration, weak judicial capacity and legal uncertainty remain the main obstacle to industrial competitiveness and economic growth in EU member states (European Commission, 2014; Ravšelj and Hodžić, 2020). In this paper, we concentrate on administrative barriers that SMEs are facing in two new EU countries, because in many cases, private business in transition countries must struggle with governmental interference, corruption and environmental changes on a much larger scale than in advanced western economies (Aidis, 2005).

\subsection{Administrative Obstacles}

Administrative barriers represent a collective name for administrative obstacle, which should be differentiated from administrative burden. Administrative barriers represent all the things that unjustifiable complicate business activities and operations of the company, as opposed to administrative burdens that can be broadly defined as all costs that results from mandatory obligations placed on businesses by public authorities on the basis of laws, degree or similar acts. Administrative burdens differ among European countries and include: (a) EU law and domestic legal acts required to transpose it into national law; (b) accounting and taxation requirements; as well as (c) sectoral and industrial specific laws reporting and coordinating 
obligations (Szczepaǹski, 2016). Administrative barriers represent costs to companies and citizens in fulfilling fundamental obligations based on government laws and regulations (European Commission, 2014). It can be defined as (recurring) costs of administrative activities that companies have to perform in order to comply with their obligations imposed by central government regulation (UK Cabinet Office, 2006; Cristea and Thalassinos, 2016).

The imposition of the often severely restrictive regulatory obligations for SMEs has led the European Commission to introduce special action plans in order to simplify and improve the regulatory environment. The main drivers behind "Better Regulation Programs" presume that a stronger focus on reducing administrative burden on companies would lead to better policies, better implementation, better coordination and, finally, better government (UK Cabinet Office, 2006). In an official document "Better Regulation for Growth and Jobs in the European Union", the Commission encourages Member States to continue to develop independently improved administrative regulations (European Commission, 2005). Within the framework of the Lisbon Agenda, the European Commission has launched its "Better Regulation" program. In order to adopt this Agenda by the beginning of 2007, the Commission adopted the "Action Program for reducing administrative costs in the European Union". The Action Plan was approved by the European Council, which emphasized the main goal for reducing administrative burdens which is arising from the EU law for $25 \%$ by 2012 . Such a reduction could lead to an increase in GDP by $1.4 \%$ (European Commission, 2007).

Economic literature broadly classifies barriers to SMEs' growth and development in three main categories: internal (for example, insufficient skills and resources at enterprise level), administrative (for example, tax systems, and complicated laws) and financial (mostly access to finance). The last comprehensive pre-crisis Eurobarometer survey from 2007, which was focused on the specific difficulties of SMEs showed that the biggest problems were the strict administrative regulations, the low availability and the cost of appropriate human resources (almost one third of the companies claimed facing difficulties in the areas), insufficient infrastructure and limited access to finance (more than $20 \%$ of SMEs reported difficulties in this area) (Szczepanski, 2016). The facts show that SMEs bear disproportionately greater regulatory and administrative barriers than large companies.

Various studies conclude that for smaller entities the cost of coordination with regulatory burdens and requirements is disproportionately high. The total cost of the administrative burdens as percentage of GDP varies across the EU members. Italy, Spain, Poland, Greece and Hungary report the highest levels (between $4.6 \%$ and $6.8 \%$ of GDP), while Finland, Sweden, the United Kingdom, Denmark and Ireland report the lowest (between 1.5\% and 2.4\% of GDP). The burden on SMEs is large due to frequent failure, which do not take the specific characteristics of small economies business into account when designing laws, as well as the nature of regulatory burdens. The duties and obligations are often the same for smaller and 
larger businesses, but SMEs are less efficient in solving regulations (for example, they invest less in IT support systems, but also in smaller businesses, entrepreneurs spend their valuable time on solving compliance and reporting) (Szczepaǹski, 2017). Experts estimate that while large companies pay 1.0 EUR per employee for regulatory obligations, small businesses pay for the same costs up to 10.0 EUR. Studies indicate that companies with fewer than ten employees has to face regulatory burden (measured per employee), that is almost double the burden of a business with more than 10 but less than 20 employees and almost three times as high as the burden of a company with more than 20 but fewer than 50 employees. For large companies, the burden per-employee is only one fifth or less of that of small enterprises. Uneven regulatory burden exist for several reasons, such as: (i) coordination with regulations has the characteristics of fixed costs (for example, information duties may be the same for small and large enterprises), (ii) small and medium enterprises are less efficient in dealing with regulations (for example, they invest less in specific computerization) and (iii) it is often entrepreneurs themselves that have to deal with regulations (Szczepaǹski, 2016).

For years, the European Parliament is stating in its resolutions that the specific obstacles faced by SMEs are the result of their small size (Szczepaǹski, 2017). Since 2011, European Parliament has consistently being emphasizing that reducing administrative barriers, better access to financial opportunities and supporting the creation of a competitive environment is a key issue to enable successful business development and job creation (European Parliament, 2017). The European Commission (EC) and the European Central Bank (ECB) carry out joint annual surveys on enterprise financing access and also address the most critical issues that SMEs are facing. Among the six biggest problems identified by enterprises in the period 2014-2019 are customer finding, availability of expert staff and managers, competition, regulation, production or labour costs and access to finance as they are shown in Figure 1.

Figure 1. The biggest problems faced by small and medium-sized enterprises in the EU-28, 2014-2019

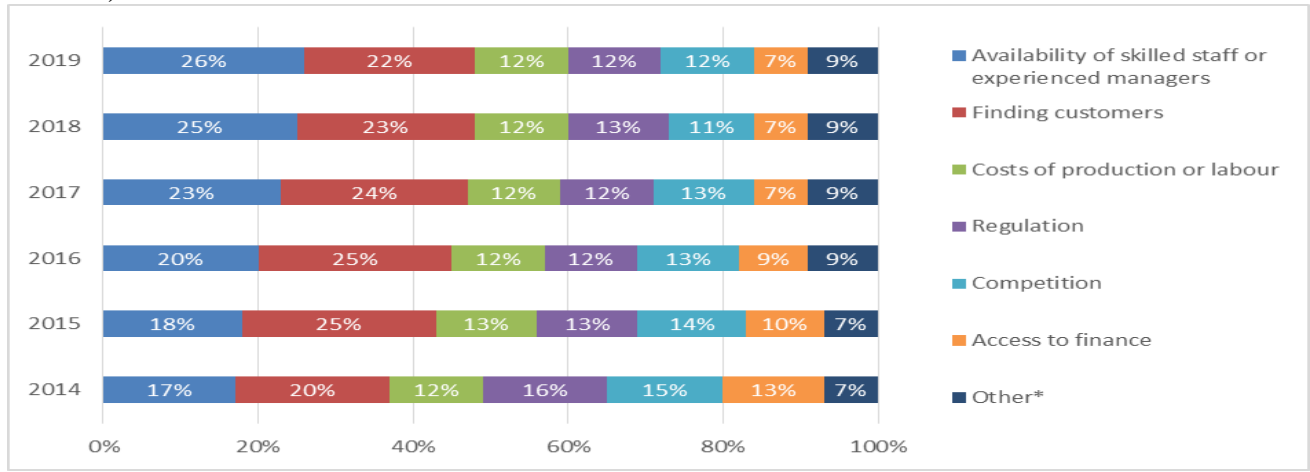

Note: $*$ The data is rounded.

Source: European Commission (2019b). 
The ranking of all of the above-mentioned problems is calculated based on grades of respondents who were asked to assign a fixed set of problems. Accordingly, the problem with the highest importance is considered as the most pressing problem faced by SMEs. Considering all of the potential problems and time dimension, SMEs point out the availability of skilled staff or experienced managers and finding customers as the most frequent problems. Currently, the problem of availability of skilled staff or experienced managers represents the most pressing problem for SMEs. This problem has steadily increased every year since 2014 and now is considered as the most frequent problem for more than a quarter of SMEs (26\%).

The second most pressing problem is finding customers for products or services (22\%). After 2016, this problem was in the phase of decline, meaning that the position of SMEs has improved in last years as the demand on their market is approaching the pre-crisis level. The third most pressing problem is represented by the costs of production or labour occupies (12\%), while the fourth and fifth problem are regulation (12\%) and competition (12\%). All of these three problems have been fairly stable since 2014. Finally, the problem related to the access to finance has dropped to be the least pressing of all-possible problems identified (7\%) as it has steadily declined in importance throughout the observed period. The following Figure 2 provides a breakdown of the most pressing problems SMEs face in EU-28, Croatia and Slovenia, whereby the proportions of the EU-28 correspond to those in the previous figure.

Figure 2. The biggest problems faced by small and medium-sized enterprises in the EU-28, Croatia and Slovenia in 2019

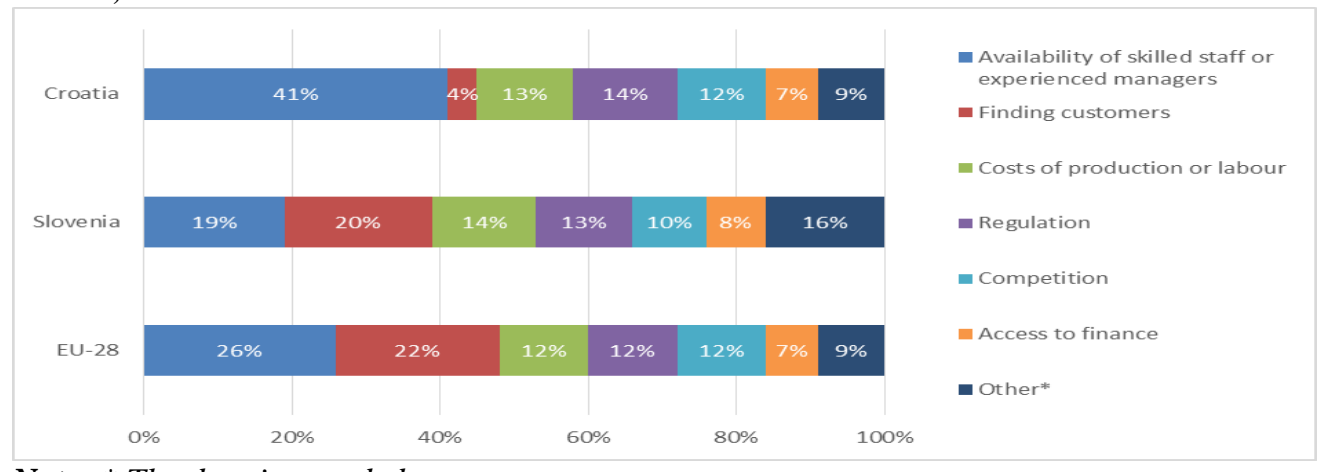

Note: * The data is rounded.

Source: European Commission (2019b).

The comparison between Croatia and Slovenia and EU-28 reveals significant differences. The most obvious differences can be observed especially in the availability of skilled staff or experienced and finding customers. The former is considered as the most pressing problem $(41 \%)$, while the latter is considered as the least pressing problem (4\%) for SMEs in Croatia. For Slovenia, however, both of these problems are considered as the most pressing problems, having similar proportion of SMEs emphasizing them as the most frequent problems. Moreover, the 
large gap can be observed also in finding customers, which is significantly lower in Croatia $(4 \%)$ than in Slovenia $(20 \%)$. As regards other four identified problems (costs of production or labour, regulation, competition and access to finance) the position of SMEs is similar regardless of the country of origin. Nevertheless, there are still more than $12 \%$ of SMEs on the EU-28 level, pointing out regulation as their most frequent problem. This share is higher for Slovenia (13\%) and even higher for Croatia (14\%), often resulting from rigidity and administrative barriers at the labour market.

\subsection{Rules and Barriers at the Labour Market}

Creating new jobs in SMEs is never driven by just one factor (Kambey et al., 2018; Nawangsari and Sutawidjaya, 2019; Setyawati, et al., 2019). At the beginning of 2016, the European Union Agency, Eurofound, announced a study on a group of various barriers to job creation faced by SMEs in the EU-28 area. It is concluded that barriers can be external and internal. External barriers include administrative and institutional business environment (for example, regulation of working hours, rigid working law), the existing macroeconomic situation (and the resulting decline in demand, increase in payment delays and more difficult access to finance), competition from major or multinational companies and grey economy, and high labour costs, associated with the low availability of skilled work force. Internal barriers include the economic performance of SMEs, lack of strategic planning, low internationalization and innovation ability, inefficient organizational structure and management capability, inability to attract workers, as well as low motivation and negative attitude of owners or managers (Eurofound, 2016).

Labour market rules can have significant effects on the overall economic activity of a national economy. World Bank data, published in the Doing Business report, show that rigid employment regulation is associated with higher levels of informality, mild labour market rules can lead to discrimination and mistreatment of employees. The above mentioned report measures several aspects of labour market rules employment, working hours, dismissal rules and their costs for 190 countries in the world. According to this data, it can be concluded that economies with more flexible labour market regulations have a higher share in officially registered companies and a larger share of pension insurers, who can serve as a substitute variable for official employment (World Bank Group, 2017; 2020).

Today, governments challenge the avoidance of extreme amounts of regulation and over-regulation on the one hand and balancing the labour flexibility with security and worker protection on the other (World Bank, 2012). Employment protection legislation (EPL) - rules governing employment and dismissal - is designed to improve worker welfare and prevent discrimination. On the average, enterprises in the informal sector have lower values added per employee and pay lower wages than companies in the formal sector (World Bank Group, 2017; 2020). 
Existing economic literature highlights the administrative and institutional business environment as a crucial factor in job creation in SMEs in all EU member states (OECD, 2010; Napier et al., 2012; Criscuolo et al., 2014; Lee, 2014). For example, in Sweden, almost $40 \%$ of entrepreneurs believe that administrative barriers and legislation are the biggest obstacle to business development and growth. In Estonia, $38 \%$ of SMEs emphasize burdensome legislation and excessive bureaucracy as a problem, while in Germany one-fifth of enterprises consider that unnecessary bureaucratic procedures (red tape) related to environment protection standards, taxation and labor or social law has risen significantly over the past five years. The quality of public institutions also affects the level of employment in SMEs. Specific factors in this context include the level of transparency of public administration and its implementation of controls and sanctions, the efficiency and length of the public authorities decision-making, as well as corruption, which is especially evident in the case of Croatia and Italy. The unequal perception of entrepreneurship, including the stigmatization of the failure and the reluctance to give "other opportunities", is a barrier to creating new jobs in SMEs. An unfavourable perception of entrepreneurship especially in the form of SMEs negatively affects the potential number of newly established companies that might create jobs later on (Eurofound, 2016).

At the top of the problems that are caused by other numerous restrictions, such as the complexity and incomprehensibility of a large number of different labour market regulations, are slowing growth and job creation, not only in Germany, but also in the international content (Pierre and Scarpetta, 2004). Gauthier and Gerzovits (1997) suggested that there are fewer middle-sized companies because they face the highest tax rates and labour costs, since smaller enterprises can choose to remain informal in order to avoid paying taxes, and larger companies seek to lobby for special treatment.

Design and content of legal regulations are not the only factors that make it difficult to create new jobs in SMEs. The problem is also their stability. Frequent changes in legal regulations are very challenging for SMEs and unfortunately can have a negative impact on creating new jobs. For example, since 2006, around 500 regulations have been introduced and changed in Croatia, which need to be continuously monitored and adapted by companies (Eurofound, 2016). Similarly, in Slovenia, regulation and inefficient government bureaucracy is considered as a highly problematic factor affecting SME competitiveness. Moreover, recent Europeanization and globalization processes have made this problem even more prominent for both countries (Ropret et al., 2018).

The Croatian labour market, as in most other EU member states, is characterized by relatively high "rigidity in the labour market". Rigidity of labour market are primarily related to complicated and expensive hiring and dismissal procedures, excessive minimum wage, extreme unemployment benefits, excessive workers protection, unions' power, and other. To some extent, the similar patterns can be 
observed also in Slovenian labour market. This is also confirmed by the data of the World Bank, which investigated the level of rigidity in the Croatian and Slovenian labour market that SMEs have to face. The World Bank database - Doing Business measures several aspects of labour market regulation. This database collects data on four aspects of labour market regulation - hiring, working hours, redundancy rules and costs (World Bank Group, 2017; 2020). The following Table 3 shows four labour market regulation measures in Croatia and Slovenia.

Table 3. Indicators of labour market regulation in Croatia and Slovenia

\begin{tabular}{|c|c|c|c|c|c|c|c|c|c|c|c|}
\hline \multicolumn{3}{|l|}{ 1) Hiring } & \multicolumn{3}{|c|}{ 2) Working hours } & \multicolumn{3}{|c|}{ 3) Redundancy rules } & \multicolumn{3}{|c|}{ 4) Redundancy costs } \\
\hline Indicator & $\begin{array}{l}\text { HR } \\
\text { V }\end{array}$ & SVN & Indicator & $\begin{array}{l}\text { HR } \\
\text { V }\end{array}$ & $\begin{array}{l}\text { SV } \\
\mathrm{N}\end{array}$ & Indicator & $\begin{array}{l}\text { HR } \\
V\end{array}$ & $\begin{array}{l}\text { SV } \\
\mathrm{N}\end{array}$ & Indicator & $\begin{array}{l}\text { HR } \\
\text { V }\end{array}$ & $\begin{array}{l}\text { SV } \\
\mathrm{N}\end{array}$ \\
\hline \multirow{2}{*}{$\begin{array}{l}\text { Fixed- } \\
\text { term } \\
\text { contracts } \\
\text { prohibite } \\
\text { d for } \\
\text { permanen } \\
\text { t tasks? }\end{array}$} & \multirow{2}{*}{ Yes } & \multirow{2}{*}{ Yes } & $\begin{array}{l}\text { Standard } \\
\text { workday }\end{array}$ & 8.0 & 8.0 & $\begin{array}{l}\text { Dismissal } \\
\text { due to } \\
\text { redundancy } \\
\text { allowed by } \\
\text { law? }\end{array}$ & Yes & Yes & \multirow{3}{*}{$\begin{array}{l}\text { Notice } \\
\text { period for } \\
\text { redundancy } \\
\text { dismissal } \\
\text { (weeks of } \\
\text { salary) }\end{array}$} & \multirow{3}{*}{7.9} & \multirow{3}{*}{5.3} \\
\hline & & & $\begin{array}{l}\text { Maximu } \\
\text { m } \\
\text { working } \\
\text { days per } \\
\text { week }\end{array}$ & 6.0 & 6.0 & $\begin{array}{l}\text { Third-party } \\
\text { notification } \\
\text { if one } \\
\text { worker is } \\
\text { dismissed? }\end{array}$ & Yes & No & & & \\
\hline \multirow{2}{*}{$\begin{array}{l}\text { Maximu } \\
\text { m length } \\
\text { of a } \\
\text { single } \\
\text { fixed- } \\
\text { term } \\
\text { contract } \\
\text { (months) }\end{array}$} & \multirow{2}{*}{$\begin{array}{l}\text { No } \\
\text { limi } \\
t\end{array}$} & \multirow{2}{*}{24} & $\begin{array}{l}\text { Restricti } \\
\text { ons on } \\
\text { night } \\
\text { work? }\end{array}$ & Yes & No & $\begin{array}{l}\text { Third-party } \\
\text { approval if } \\
\text { one worker } \\
\text { is } \\
\text { dismissed? }\end{array}$ & No & No & & & \\
\hline & & & $\begin{array}{l}\text { Restricti } \\
\text { ons on } \\
\text { weekly } \\
\text { holiday } \\
\text { work? }\end{array}$ & Yes & No & $\begin{array}{l}\text { Third-party } \\
\text { notification } \\
\text { if nine } \\
\text { workers are } \\
\text { dismissed? }\end{array}$ & Yes & No & \multirow{3}{*}{$\begin{array}{l}\text { Severance } \\
\text { pay for } \\
\text { redundancy } \\
\text { dismissal } \\
\text { (weeks of } \\
\text { salary) }\end{array}$} & \multirow{3}{*}{7.2} & \multirow{3}{*}{5.3} \\
\hline $\begin{array}{l}\text { Maximu } \\
\text { m length } \\
\text { of fixed- } \\
\text { term } \\
\text { contracts } \\
\text { (months) }\end{array}$ & $\begin{array}{l}\text { No } \\
\text { limi } \\
t\end{array}$ & 24 & $\begin{array}{l}\text { Restricti } \\
\text { ons on } \\
\text { overtime } \\
\text { work? }\end{array}$ & No & No & $\begin{array}{l}\text { Third-party } \\
\text { approval if } \\
\text { nine } \\
\text { workers are } \\
\text { dismissed? }\end{array}$ & No & No & & & \\
\hline $\begin{array}{l}\text { Minimum } \\
\text { wage for } \\
\text { a full- } \\
\text { time } \\
\text { worker } \\
\text { (US } \$ / \text { mo } \\
\text { nth) }\end{array}$ & $\begin{array}{l}569 . \\
3\end{array}$ & $\begin{array}{l}1000 \\
.2\end{array}$ & $\begin{array}{l}\text { Paid } \\
\text { annual } \\
\text { leave for } \\
\text { a worker } \\
\text { with 1 } \\
\text { year of } \\
\text { tenure } \\
\text { (in } \\
\text { working } \\
\text { days) } \\
\end{array}$ & $\begin{array}{l}20 . \\
0\end{array}$ & $\begin{array}{l}20 . \\
0\end{array}$ & $\begin{array}{l}\text { Retraining } \\
\text { or } \\
\text { reassignme } \\
\text { nt? }\end{array}$ & No & No & & & \\
\hline $\begin{array}{l}\text { Ratio of } \\
\text { minimum } \\
\text { wage to } \\
\text { value } \\
\text { added per } \\
\text { worker }\end{array}$ & 0.3 & 0.3 & $\begin{array}{l}\text { Paid } \\
\text { annual } \\
\text { leave for } \\
\text { a worker } \\
\text { with } 5 \\
\text { years of } \\
\text { tenure } \\
\text { (in } \\
\text { working }\end{array}$ & $\begin{array}{l}20 . \\
0\end{array}$ & $\begin{array}{l}22 . \\
0\end{array}$ & $\begin{array}{l}\text { Priority } \\
\text { rules for } \\
\text { redundanci } \\
\text { es? }\end{array}$ & Yes & No & $\begin{array}{l}\text { Unemploy } \\
\text { ment } \\
\text { protection } \\
\text { after one } \\
\text { year of } \\
\text { employmen } \\
\text { t? }\end{array}$ & Yes & Yes \\
\hline
\end{tabular}




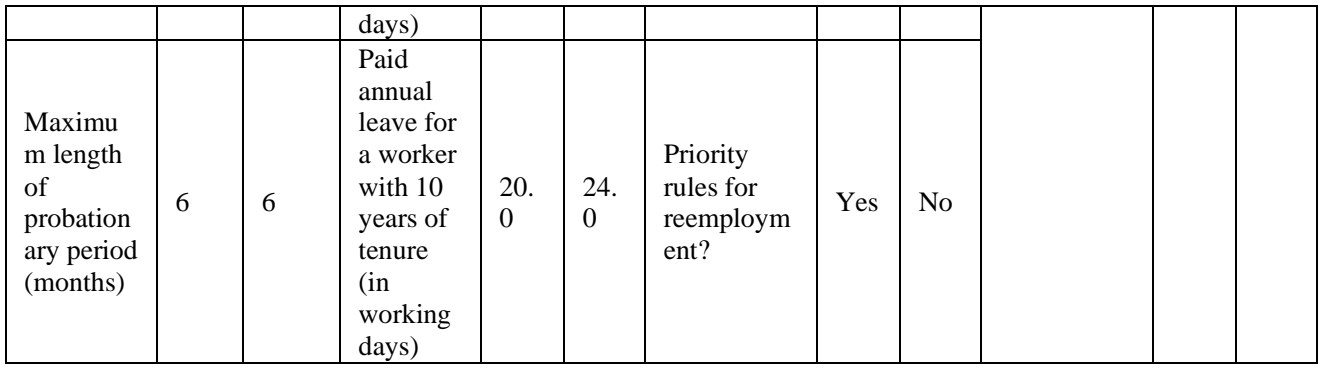

Source: World Bank Group (2020).

Compared to other EU countries, Croatia and Slovenia still have relatively strict labour market regulations, which is a major obstacle for SMEs' development (Obadić et al., 2017; Obadić, 2018; OECD, 2009). As far as hiring procedures are concerned, Croatia and Slovenia still have fixed-term contracts prohibited for permanent tasks. However, the maximum length of fixed-term contracts is not limited in Croatia, while in Slovenia they are limited to 24 months. In comparison with Slovenia, Croatia has relatively small minimum wage for a full-time worker, whereby the ratio of minimum wage to value added per worker is on the same level.

The same limitation also exist for the length of probationary period. In terms of working hours, the standard workday and working days per week are the same in both countries. Moreover, restrictions on night and weekly holiday work exist for Croatia, while for Slovenia not. However, there are no restrictions on overtime work in both countries. Furthermore, paid annual leave for a worker is not dependent on years of tenure in Croatia, while this is not the case for Slovenia. Taking into account the rules and costs of dismissal, the dismissal due to redundancy is allowed by law in both countries. However, in Croatia, the government requires notifying the thirdparty for redundancy dismissal, while in Slovenia this is not required. Additionally, in Croatia there exist also some priority rules for redundancies and re-employment. Compared to Slovenia, notice period and severance pay for redundancy dismissal are more extensive (World Bank Group, 2017; 2020).

\section{Data and Research Method}

The paper focuses on identifying external barriers to job creation, especially those aimed at the administrative and institutional business environment of SMEs. In order to estimate the existing state of working regulations on the various individual characteristics of SMEs connected to administrative barriers to the employment and dismissal process in Croatia and Slovenia, and to examine the research questions, a primary research was conducted.

The data for the research is collected using a questionnaire. The content of the questionnaire was formed by academia experts in the economics and law fields together with the recommendations provided by the practitioners, i.e., representatives of the Croatian Employers' Association, the Croatian Chamber of Trades and Crafts 
and the Slovenian Chamber of Craft and Small Business. The questionnaire contains about 40 questions and cover different key fields, where SMEs can face administrative barriers, whereby the respondents could leave certain questions blank if the content was not appropriate to them. The questionnaire was distributed via two paths, namely through the web and field survey. The survey for Croatia has been running from $5^{\text {th }}$ December 2016 to $31^{\text {st }}$ March 2017 in Croatia and form $7^{\text {th }}$ November 2016 to $29^{\text {th }}$ April 2017 in Slovenia. It resulted in 960 replies in Croatia and 925 replies in Slovenia, including those who only partially answered the questionnaire.

For the purpose of the empirical analysis, only those questions related to the area of labour market regulation are taken into account. Moreover, in the sample is reduced for those enterprises, which cooperate only with one business partner from the beginning of their foundation, since these are so-called fictitious enterprises. This is particularly problematic in the Slovenian context. Finally, the sample is also reduced for those companies, which did not fully answer the questions that represent the main variables in the empirical analysis. Accordingly, the final sample includes 699 Croatian and 747 Slovenian SMEs. The final sample covers SMEs from all Croatian and Slovenian regions, which means that representative coverage of all regions in the sample has been achieved for both countries.

Table 4 shows the structure of the sample of SMEs by Croatian regions and comparison with the SMEs population. The majority of SMEs included in the sample are from the City of Zagreb region (30\%). This is in line with the official Croatian business statistics showing the largest share of SMEs are operating in that region $(35 \%)$. Regarding the remaining regions, the sample structure corresponds to the structure presented by the Croatian official business statistics.

Table 4. Sample structure by Croatian regions and comparison with the SME population

\begin{tabular}{|c|c|c|c|c|}
\hline \multirow{2}{*}{ Region } & \multicolumn{2}{|c|}{ Official source } & \multicolumn{2}{|l|}{ Sample } \\
\hline & Number & Share $(\%)$ & Number & Share $(\%)$ \\
\hline City of Zagreb & 58,291 & $35 \%$ & 209 & $30 \%$ \\
\hline Zagreb County & 10,707 & $6 \%$ & 90 & $13 \%$ \\
\hline Primorje-Gorski Kotar & 14,997 & $9 \%$ & 69 & $10 \%$ \\
\hline Split-Dalmatia & 18,332 & $11 \%$ & 44 & $6 \%$ \\
\hline Vukovar-Srijem & 2,308 & $1 \%$ & 35 & $5 \%$ \\
\hline Istria & 14,119 & $8 \%$ & 33 & $5 \%$ \\
\hline Varaždin & 4,958 & $3 \%$ & 32 & $5 \%$ \\
\hline Međimurje & 4,401 & $3 \%$ & 23 & $3 \%$ \\
\hline Osijek-Baranja & 6,763 & $4 \%$ & 20 & $3 \%$ \\
\hline Krapina-Zagorje & 2,704 & $2 \%$ & 19 & $3 \%$ \\
\hline Bjelovar-Bilogora & 2,593 & $2 \%$ & 18 & $3 \%$ \\
\hline Šibenik-Knin & 2,966 & $2 \%$ & 15 & $2 \%$ \\
\hline Sisak-Moslavina & 2,653 & $2 \%$ & 14 & $2 \%$ \\
\hline Virovitica-Podravina & 1,330 & $1 \%$ & 13 & $2 \%$ \\
\hline
\end{tabular}




\begin{tabular}{|l|l|l|l|l|}
\hline Zadar & 5,269 & $3 \%$ & 13 & $2 \%$ \\
\hline Dubrovnik-Neretva & 5,519 & $3 \%$ & 11 & $2 \%$ \\
\hline Brod-Posavina & 2,595 & $2 \%$ & 10 & $1 \%$ \\
\hline Koprivnica-Križevci & 2,401 & $1 \%$ & 9 & $1 \%$ \\
\hline Karlovac & 2,861 & $2 \%$ & 8 & $1 \%$ \\
\hline Lika-Senj & 1,090 & $1 \%$ & 7 & $1 \%$ \\
\hline Požega-Slavonia & 1,146 & $1 \%$ & 7 & $1 \%$ \\
\hline Total & 168,003 & $100 \%$ & 699 & $100 \%$ \\
\hline
\end{tabular}

Source: HGK (2016); FINA (2016); Questionnaire Survey (2017); authors' elaboration.

Table 5 shows the structure of the sample of SMEs according to the Slovenian counties. The majority of SMEs included in the sample are from Central Slovenia region (48\%). This is in line with the official Slovenian business statistics showing the largest share of SMEs are operating in that region (33\%). Regarding the remaining regions, the sample structure corresponds to the structure presented by the Slovenian official business statistics.

Table 5. Sample structure by Slovenian regions and comparison with the SME population

\begin{tabular}{|l|l|l|l|l|}
\hline \multirow{2}{*}{ Region } & \multicolumn{3}{l|}{ Official source } & \multicolumn{2}{l|}{ Sample } \\
\cline { 2 - 5 } & Number & Share (\%) & Number & Share (\%) \\
\hline Central Slovenia & 65,412 & $33 \%$ & 360 & $48 \%$ \\
\hline Upper Carniola & 19,462 & $10 \%$ & 63 & $8 \%$ \\
\hline Drava & 26,125 & $13 \%$ & 54 & $7 \%$ \\
\hline Gorizia & 11,705 & $6 \%$ & 50 & $7 \%$ \\
\hline Savinja & 21,490 & $11 \%$ & 40 & $5 \%$ \\
\hline Lower Sava & 5,772 & $3 \%$ & 28 & $4 \%$ \\
\hline Coastal-Karst & 13,855 & $7 \%$ & 28 & $4 \%$ \\
\hline Carinthia & 5,526 & $3 \%$ & 27 & $4 \%$ \\
\hline Central Sava & 3,916 & $2 \%$ & 27 & $4 \%$ \\
\hline Mura & 7,983 & $4 \%$ & 24 & $3 \%$ \\
\hline Southeast Slovenia & 10,378 & $5 \%$ & 24 & $3 \%$ \\
\hline Littoral-Inner Carniola & 4,448 & $2 \%$ & 22 & $3 \%$ \\
\hline Total & 196,072 & $100 \%$ & 747 & $100 \%$ \\
\hline Note:
\end{tabular}

Note: The official source provides regional level data only for total number of enterprises in Slovenia.

Source: SURS (2016); Questionnaire Survey (2017); authors' elaboration.

For the purpose of the empirical analysis, SMEs are divided according to four demographic criteria: size, legal form, sector and region. According to the size, SMEs are divided into micro enterprises (less than 10 employees), small enterprises (10-49 employees) and medium-sized enterprises (50-249 employees). Considering the legal form, SMEs are divided into private limited companies, individual entrepreneurs and other companies (e.g. public limited companies, limited partnerships, private unlimited companies, economic interest groupings etc.). According to the sector, SMEs are divided into manufacturing (NACE A-F) and 
non-manufacturing (G-U) enterprises. Finally, SMEs are also divided depending on the (NUTS-2) region in which they operate into more developed region (Continental Croatia or Western Slovenia) and less developed region (Adriatic Croatia or Eastern Slovenia). The presented division of SMEs allows to identify potential differences between the individual groups of SMEs regarding the extent of administrative barriers to employment.

According with the twofold aim of the paper, the first part of the empirical analysis covers a general overview of the perception of SMEs on possible administrative barriers to employment, while the second part provides more in-depth one-way analysis of variance (ANOVA) by analysing the variable "the extent of administrative barriers to employment". The reason for choosing this statistical method is based on research design applied in the paper. Namely, this parametric statistical technique is a robust and commonly used method for detecting differences in averages between different groups (Bower, 2000; Rasch et al., 2007). Table 6 presents seven statements related to administrative barriers to employment.

Table 6. Potential administrative barriers to employment

\begin{tabular}{|l|l|}
\hline No. & Question \\
\hline 1 & It requires additional time to implement the required procedures and activities. \\
\hline 2 & $\begin{array}{l}\text { It requires additional financial resources to implement the required procedures and } \\
\text { activities. }\end{array}$ \\
\hline 3 & Changes in various regulations are too frequent. \\
\hline 4 & The number of different procedures is excessive. \\
\hline 5 & $\begin{array}{l}\text { It requires additional personal communication of a company with administrative } \\
\text { authorities. }\end{array}$ \\
\hline 6 & Excessive number of different documents is needed. \\
\hline 7 & Additional support/external services is/are needed. \\
\hline
\end{tabular}

Source: Questionnaire Survey (2017); authors' elaboration.

The main variable "the extent of administrative barriers to employment" is measured on a scale from 0 to 3, given that each item can be assessed with a value of 0 or 1 and each enterprise could select up to 3 of the 7 items, which represent the largest administrative barrier for them, and therefore value 3 represents maximum. The empirical results are presented in two parts. The first part utilizes descriptive statistics for the presentation of relative frequencies, while the second part provides the presentation of ANOVA results.

\section{Empirical Results}

The first part of the empirical results shows a general overview of possible administrative barriers to employment, which are faced by SMEs in Croatia and Slovenia (Figure 3). In Croatia, the majority (54\%) of SMEs identify frequent changes in the regulation as the most burdensome potential administrative barrier to employment. Further, more than one third (34\%) of SMEs emphasize that they need 
outsourcing to perform administrative tasks related to employment. One third (33\%) of SMEs argue that employment administrative tasks require excessive number of documents, while $31 \%$ of SMEs think that they require excessive number of procedures. In addition, $31 \%$ of SMEs state that employment administrative tasks require extra time. Finally, extra personal communication (15\%) and extra financial resources $(9 \%)$ are perceived as the least burdensome potential administrative barriers to employment for SMEs in Croatia.

In Slovenia, the largest share (41\%) of SMEs identify extra time and excessive number of documents as the most burdensome potential administrative barriers to employment. Further, more than one third (37\%) of SMEs point out that the main problem related to the employment lays in the frequent changes in the regulation, while about one third (34\%) of SMEs sees the central problem in excessive number of procedures. Additionally, $31 \%$ of SMEs emphasize that they need outsourcing to perform administrative tasks related to employment. Finally, extra financial resources (23\%) and extra personal communication (7\%) are perceived as the least burdensome potential administrative barriers to employment for SMEs operating in Slovenia.

Figure 3. Perception of administrative barriers to employment

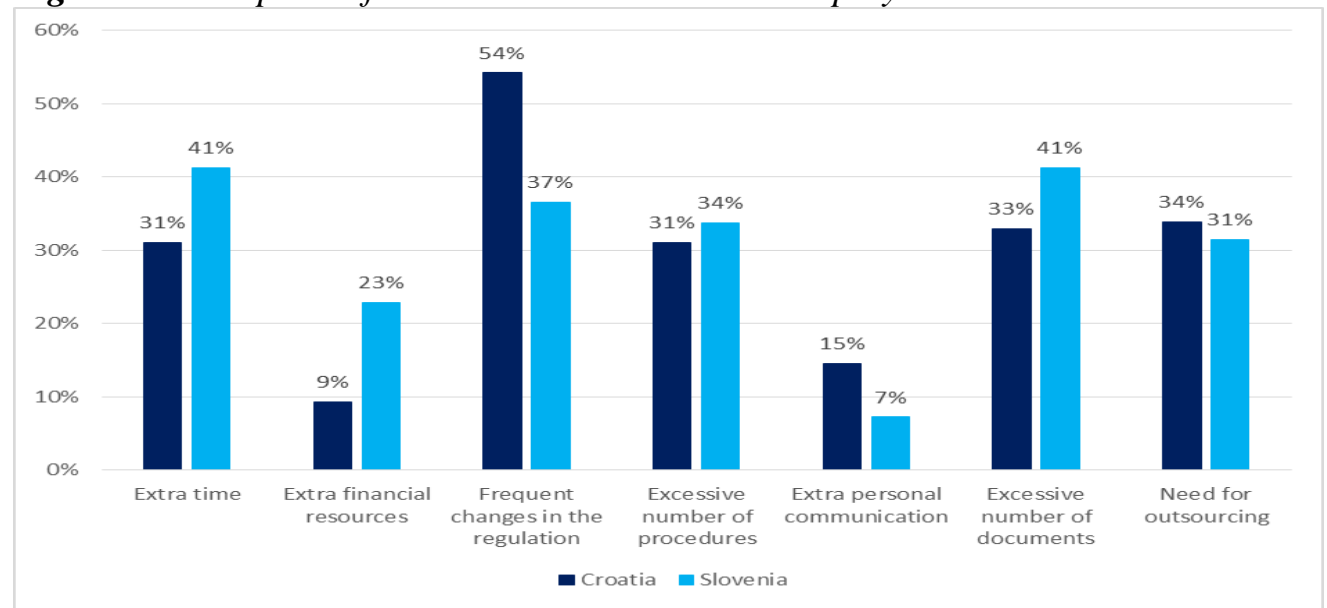

Note: Croatia ( $N=699)$, Slovenia $(N=747)$.

Source: Questionnaire Survey (2017); authors' elaboration.

A comparison between Croatia and Slovenia reveals some differences and similarities regarding the perception of administrative barriers to employment. It can be observed that Croatian SMEs perceive administrative barriers to employment from the perspective frequent changes regulation and extra personal communication, while Slovenian SMEs perceive them from the perspective of additional (time and financial) resources and excessive number of documents. Moreover, a similar perception of Croatian and Slovenian SMEs can be observed for excessive number of procedures and need for outsourcing. 
The second part of empirical results consists of more in-depth analysis for the purposes of examining whether the characteristics of SMEs affect the perception of the extent of administrative barriers to employment. The results of one-way ANOVA analysis on the perception of the extent of administrative barriers to employment for Croatia and Slovenia are presented in Table 7.

Table 7. The results of ANOVA analysis on the perception of the extent of administrative barriers to employment for Croatia and Slovenia

\begin{tabular}{|c|c|c|c|c|c|c|c|}
\hline \multicolumn{2}{|c|}{ SME characteristics } & \multicolumn{2}{|c|}{ Sample } & \multicolumn{2}{|l|}{ Mean } & \multicolumn{2}{|c|}{ P-value } \\
\hline Category & Group & HRV & SVN & HRV & SVN & HRV & SVN \\
\hline \multirow{3}{*}{ Size } & Micro enterprises & 527 & 593 & 2.135 & 2.111 & \multirow{3}{*}{$0.030^{*}$} & \multirow{3}{*}{0.120} \\
\hline & Small enterprises & 132 & 99 & 1.932 & 2.323 & & \\
\hline & Medium-sized enterprises & 40 & 55 & 1.675 & 2.164 & & \\
\hline \multirow{3}{*}{ Legal form } & Private limited companies & 531 & 362 & 1.994 & 2.141 & \multirow{3}{*}{$0.001^{*}$} & \multirow{3}{*}{$0.028^{*}$} \\
\hline & Individual entrepreneurs & 134 & 342 & 2.433 & 2.099 & & \\
\hline & Other companies & 34 & 43 & 1.824 & 2.512 & & \\
\hline \multirow{2}{*}{ Sector } & Manufacturing & 172 & 181 & 2.023 & 2.171 & \multirow{2}{*}{0.572} & \multirow{2}{*}{0.649} \\
\hline & Non-manufacturing & 527 & 566 & 2.085 & 2.134 & & \\
\hline \multirow{2}{*}{ Region } & More developed region & 507 & 501 & 2.075 & 2.094 & \multirow{2}{*}{0.868} & \multirow{2}{*}{$0.043^{*}$} \\
\hline & Less developed region & 192 & 246 & 2.057 & 2.244 & & \\
\hline
\end{tabular}

Note: * The result is significant at $95 \%$ level $(P \leq 0.05)$.

Source: Questionnaire Survey (2017); authors' elaboration.

According to the size, the largest extent of administrative barriers to employment is perceived by micro enterprises in Croatia (2.135) and small enterprises in Slovenia (2.323). On the other hand, the smallest extent of administrative barriers to employment is perceived by medium-sized enterprises (1.675) in Croatia and micro enterprises in Slovenia (2.111). However, the differences between size groups are significant only for the Croatian sample of SMEs. Moreover, according to the legal form, individual enterprises in Croatia (2.433) and other companies in Slovenia (2.512) perceive the largest extent of administrative barriers to employment.

On the contrary, other companies in Croatia and individual entrepreneurs in Slovenia perceive the smallest extent of administrative barriers to employment. The differences between legal form groups are significant for both, Croatia and Slovenia. Based on the presented results, it is evident, that in general, smaller SMEs experience larger extent of administrative barriers than larger ones. This is especially obvious for Croatian SMEs. This is in accordance with the initial expectations, since smaller companies are often faced with disproportionately greater regulatory barriers compared to larger companies (Aristovnik and Obadić, 2015). Interestingly, the results for Slovenian micro enterprises and individual entrepreneurs slightly deviate from the presented expectations, however, that can be a reflection of higher labour flexibility for Slovenian smaller SMEs. Namely, according to the latest Doing Business Report 2020, Slovenian labour market is more flexible than Croatian, especially in the aspect of working hours and dismissal rules (World Bank Group, 2020). 
As regards the sector, the comparison between manufacturing and nonmanufacturing SMEs shows that slightly larger extent of administrative barriers to entrepreneurship are perceived by non-manufacturing SMEs in Croatia and manufacturing SMEs in Slovenia. However, the differences between sector groups are not significant for both countries. Furthermore, as regards the region the results show the following. Croatian SMEs perceive almost the same extent of administrative barriers to employment regardless of region they operate. However, in Slovenia, SMEs operating in less developed regions experience significantly higher extent of administrative barriers to employment. This is in line with the fact that SMEs operating in poorer regions are often confronted with the limitation of human and financial resources, which makes employment difficult (Aliu et al., 2019).

Based on the presented empirical results, the main research hypothesis that characteristics of SMEs affect the perception of the extent of administrative barriers to employment is confirmed. However, not all of the characteristics have the same implications on this perception. Namely, the results reveal significant differences for size category (Croatia only), significant differences for legal form category (Croatia and Slovenia), not significant differences for sector category (Croatia and Slovenia) and significant differences for region category (Slovenia only).

\section{Conclusion}

The importance of SMEs in the EU is enormous as they represent the engine of job creation and economic growth. However, there is no doubt that they are often much more sensitive to administrative difficulties in their business compared to larger enterprises. Numerous rigidities in the labour market further aggravate the job creation. This represents a contemporary issue especially in the new EU memberstates, such as Croatia and Slovenia, which are characterized by relatively high rigidity in the labour market. Accordingly, the main aim of the paper is to assess the current state of administrative barriers to employment for SMEs in Croatia and Slovenia. The paper highlights the fact that compared to other EU countries, Croatia and Slovenia still have relatively strict labour market regulations, which is a major obstacle for SMEs development. However, the comparison reveals that Slovenian labour market is more flexible than Croatian, especially in the aspect of working hours and dismissal rules, which makes business environment friendlier especially for individual entrepreneurs or smaller enterprises.

The empirical results reveal some interesting insights. As regards the administrative barriers to employment for SMEs, the most pronounced problem in Croatia is related to frequent changes in the regulation, while in Slovenia the most emphasized problem is related to extra time and excessive number of documents. Moreover, the empirical results reveal significant differences regarding the perception of the extent of administrative barriers to employment between different groups of SMEs, whereby not all of the characteristics have the same implications on this perception. The differences are significant for size category (Croatia only), significant for legal 
form category (Croatia and Slovenia), not significant for sector category (Croatia and Slovenia) and significant for region category (Slovenia only).

A number of relevant issues are beyond the scope of this paper. Accordingly, the main limitation of this paper is related to the primary online research, which can suffer from subjectivity, uncertainty in the true identity of the participants, noncompletion of the survey. Nevertheless, a representative coverage of all regions in the sample has been achieved for both countries. Although this study focuses on Croatia and Slovenia, the results discussed here may also be relevant for other new EU member-states. The situation in these countries may not be identical, but given some similar heritage and institutional change and relative new SMEs sector development, some issues can be generally applicable. Accordingly, the findings are important especially for economic policy makers, who need to consider the specific characteristics and needs of SMEs when preparing legislation.

\section{References:}

Aidis, R. 2005. Institutional barriers to small-and medium-sized enterprise operations in transition countries. Small business economics, 25(4), 305-317.

Aliu, A., Stapleton, L., Metin, H., Hajrizi, E. 2019. Web-Enabled Business in SMEs in Less Developed Regions: An Empirical Study of the Influence of Government Incentives, Physical Location and Cost. IFAC-PapersOnLine, 52(25), 29-34.

Aristovnik, A., Obadić, A. 2015. The impact and efficiency of public administration excellence on fostering SMEs in EU countries. Amfiteatru Economic Journal, 17(39), 761-774.

Belas, J., Belas, L., Cepel, M., Rozsa, Z. 2019. The impact of the public sector on the quality of the business environment in the SME segment. Administratie Si Management Public, (32), 18-31.

Bower, K.M. 2000. Analysis of Variance (ANOVA) using MINITAB. Scientific Computing and Instrumentation, 17, 64-65.

Criscuolo, C., Gal, P.N., Menon, C. 2014. The dynamics of employment growth: New evidence from 18 countries. OECD Science, Technology and Industry Policy Papers, No. 14. Paris, OECD Publishing.

Cristea, M., Thalassinos, I.E. 2016. Private Pension Plans: An Important Component of the Financial Market. International Journal of Economics and Business Administration 4 (1), 110-115, DOI: 10.35808/ijeba/95.

Eurofound. 2016. Job creation in SMEs: ERM annual report 2015. Luxembourg, Publications Office of the European Union.

European Commission. 2003. Commission Recommendation of 6 May 2003 concerning the definition of micro, small and medium-sized enterprises (2003/361/EC). Official Journal of the European Union, L 124/36.

European Commission. 2005. Better Regulation for Growth and Jobs in the European Union. Brussels: European Commission.

European Commission. 2007. Action programme for reducing administrative burdens in the European Union. Brussels, European Commission.

European Commission. 2014. Public administration scoreboard. Brussels, European Commission.

European Commission. 2019a. SBA fact sheets. Brussels, European Commission. 
European Commission. 2019b. Survey on the access to finance of enterprises (SAFE), Analytical Report 2019. Luxembourg, European Commission.

European Parliament. 2016. Barriers to SME growth in Europe. Strasbourg, European Parliament.

European Parliament. 2017. Small and Medium-sized Enterprises: Fact Sheets on the European Union. Strasbourg, European Parliament.

FINA. 2016. Registar godišnjih financijskih izvještaja. Zagreb: Financijska agencija.

Gauthier, B., Gersovitz, M. 1997. Revenue erosion through tax exemption and evasion in poor countries. Journal of Public Economics, 64(3), 404-424.

Hamplova, E., Provazníková, K. 2015. Opinion and Attitudes of Entrepreneurs of Small and Medium-Sized Business in the Czech Republic Conditions. Procedia economics and finance, 23, 942-947.

HGK. 2016. Registar poslovnih subjekata. Zagreb, Hrvatska gospodarska komora.

Hyman, E.L. 1989. The role of small-and micro-enterprises in regional development. Project Appraisal, 4(4), 197-214.

Kambey, J.P., Wuryaningrat, N.F., Kumajas, L.I. 2018. Examining Leadership and Knowledge Sharing Role on Small and Medium Enterprises Innovation Capabilities. International Journal of Economics and Business Administration, 6(1), 24-38.

Kamil, D., Kot, S., Jan, K., Gabriela, S. 2017. The perception of governmental support in the context of competitiveness of SMEs in the Czech Republic. Journal of Competitiveness, 9(3), 34.

Lee, N. 2014. What holds back high-growth firms? Evidence from UK SMEs. Small Business Economics, 43(1), 183-195.

Lewandowska, A., Stopa, M. 2019. Do SME's innovation strategies influence their effectiveness of innovation? Some evidence from the case of Podkarpackie as peripheral region in Poland. Equilibrium. Quarterly Journal of Economics and Economic Policy, 14(3), 521-536. doi: 10.24136/eq.2019.025.

Napier G., Rouvinen P., Johansson, D., Finnbjörnsson, T., Solberg, E., Pedersen, K. 2012. The Nordic Growth Entrepreneurship Review 2012, Final report. Oslo, Nordic Innovation Publication.

Nawangsari, L.C., Sutawidjaya, A.H. 2019. Talent Management in Mediating Competencies and Motivation to Improve Employee's Engagement. International Journal of Economics and Business Administration, 7(1), 140-152.

Ntaliani, M., Costopoulou, C. 2017. Reduction of administrative burdens for SMEs. Administration and Society, 49(8), 1143-1164.

Obadić, A. 2018. Administrative obstacles that small and medium-sized enterprises are facing in the employment area. Ekonomski pregled, 69(2), 163-187.

Obadić, A., Aristovnik, A. 2016. The Role of Public Administration Performance in improving the Business Environment for SMEs in the EU. Proceedings of 8th International Conference "An Enterprise Odyssey: Saving the Sinking Ship Through Human Capital”, Zagreb, Croatia, 8-11 June, 460-469.

Obadić, A., Aristovnik, A., Ravšelj, D. 2017. Analysis of Administrative Barriers for SMEs in the Field of Labour Market Regulation. Proceedings of 5th Annual Spain Business Research Conference. Global Research Institute for Business Academics, Australia: 11-12 September, Barcelona, Spain, 1-14.

OECD. 2000. Small and Medium-sized Enterprises: Local Strength, Global Reach, Policy Brief. Paris, OECD.

OECD. 2009. OECD Reviews of Labour Market and Social Policies: Slovenia 2009. Paris, OECD. 
OECD. 2010. Innovative SMEs and Entrepreneurship for Job Creation and Growth. Paris, OECD.

Pierre, G., Scarpetta, S. 2004. Employment regulations through the eyes of employers: do they matter and how do firms respond to them. IZA Discussion Paper, 1424, 1-44.

Pisar, P., Bilkova, D. 2019. Controlling as a tool for SME management with an emphasis on innovations in the context of Industry 4.0. Equilibrium. Quarterly Journal of Economics and Economic Policy, 14(4), 763-785. doi: 10.24136/eq.2019.035.

Rasch, D., Teuscher, F., Guiard, V. 2007. How robust are tests for two independent samples? Journal of Statistical Planning and Inference, 137(8), 2706-2720.

Ravšelj, D., Aristovnik, A. 2018. Administrative Barriers for SMEs in the Field of Tax Compliance and Financial and Accounting Reporting: Evidence from Slovenia. Problemy Zarządzania, 73(2), 75-90.

Ravšelj, D., Aristovnik, A. 2020. The Relationship between Tax-Related Administrative Barriers and SMEs Characteristics: Evidence from Slovenia. European Research Studies, 23(1), 381-388.

Ravšelj, D., Hodžić, S. 2020. The Role of Public Governance Practices for Business R\&D Activity in the EU. Central European Public Administration Review, 18(1), 125141.

Ravšelj, D., Kovač, P., Aristovnik, A. 2019. Tax-Related Burden on SMEs in the European Union: The Case of Slovenia. Mediterranean Journal of Social Sciences, 10(2), 6979.

Ropret, M., Aristovnik, A., Ravšelj, D. 2018. The Perception of Administrative Barriers and Their Implications for SMEs' Performance: Evidence from Slovenia. Zagreb International Review of Economics and Business, 21(SCI), 55-68.

Samitowska, W. 2011. Barriers to the development of entrepreneurship demonstrated by micro, small and medium enterprises in Poland. Economics \& Sociology, 4(2), 4249.

Setyawati, S.M., Nurfaizal, Y., Dwiatmadja, C., Anggraeni, A.I. 2019. Creative SelfEfficacy: A New Approach to Social Support and Creativity of SMEs' Owners. International Journal of Economics Business Administration, 7(1), 64-75.

SURS. 2016. Podjetja po kohezijskih in statističnih regijah. Ljubljana, Statistični urad Republike Slovenije.

Szczepaǹski, M. 2016. Barriers to SME growth in Europe. Strasbourg, European Parliament.

Szczepaǹski, M. 2017. Helping European SMEs to grow: Start-up and scale-up initiatives for business ventures in the EU. Strasbourg, European Parliament.

UK Cabinet Office. 2006. Administrative burdens - Routes to reduction. London, Better Regulation Executive.

van der Horst, R., Nijsen, A., Gulhan, S. 2017. Regulatory policies and their impact on SMEs in Europe: The case of administrative burdens. The Blackwell Handbook of Entrepreneurship, 128-149.

Virglerova, Z., Dobes, K., Vojtovic, S. 2016. The perception of the state's influence on its business environment in the SMEs from Czech Republic. Administratie si Management Public, (26), 78.

World Bank Group. 2017. Doing Business 2017. Washington DC, World Bank.

World Bank Group. 2020. Doing Business 2020. Washington DC, World Bank.

World Bank. 2012. World Development Report 2013: Jobs. Washington, DC, World Bank. 